\title{
COLLOQUIA
}

Forum Pedagogiczne

$10(2020) 2$

Submitted: 31.03 .2020

Accepted: 24.06.2020

DOI: $10.21697 /$ fp.2020.2.15

\author{
MÁRIA POTOČÁROVÁ* \\ Bratislava, Slovakia \\ ORCID ID: https://orcid.org/oooo-0oo2-6608-3449
}

\section{POLAND - SLOVAK REGIONAL RELATIONSHIPS AND DEVELOPMENT OF MINORITY SLOVAK SCHOOLS IN POLAND IN THE UPPER ORAVA REGION}

\begin{abstract}
The study deals with the situation of the minority (Slovak) education in the Upper Orava region in Poland. The situation and overall state of development of minority education is evaluated mainly from the perspective of historical development of social conditions that not only influenced the school policy, but in some aspects, also reflected the wider understood development of pedagogical thinking in Poland. Over roughly more than two centuries (from the 18th century to the present), a number of historical milestones in Polish - Slovak relationships have taken place, which also affected the functioning of Slovak minority schools in Poland. It is reflected in the territorial and language disputes that affect mainly the national identity of the Slovaks. This paper reflects on the meaning and mission of regional minority schools in this border area of Poland. It emphasizes their unifying role, promoting good coexistence and the formation of an honest and civic open national (ethnic) identity of Slovaks living in Poland in the Upper Orava region.
\end{abstract}

Keywords: minority; education; relationship; region.

\section{Introduction}

In this paper the level of Slovak minority schools in Polish Orava is assessed on the basis of the reflection on the historical and current situation on both sides and the position of the Polish national minority in Slovakia and the Slovak national minority

8 Prof. PhD habil. Mária Potočárová, professor at the Comenius University in Bratislava, Slovakia; e-mail: maria.potocarova@uniba.sk. 
in Poland. In this part of the study we will focus on the historical background of Polish-Slovak relationships. The outcome of these relationships was reflected in various transformations in the development of regional Slovak minority education in the border area of these neighboring countries. Attention is paid to the analysis and evaluation of the state of Slovak minority schools in Upper Orava. The analysis will be based mainly on the background and research findings elaborated in the dissertation of Marián Smondek (2014, p. 141), on additional literature and also on the results of some other research reports that mapped the situation in this issue.

The dispersion of the Slovak national minority in Poland is caused, in particular, by historical development and also the similarity of language and the common Slavic origin of both nations. Considering the overall ethnic composition of the population in the Republic of Poland, the number of the Slovak national minority registered in Poland is very low. Slovak language is a recognized regional language but belongs to $0.6 \%$ of other regional languages. The same can be argued about the situation of the Polish national minority living in Slovakia. Considering also the compared population of both states (roughly 39 million and 5 million respectively), there is also an understandable difference in interest in supporting and developing minority education in the border area. The historical difference of comparison, in particular, consisted in the fact that the Poles have had their own large and independent kingdom and state for centuries, unlike the Slovaks who were part of Hungary (Austro-Hungarian Monarchy). It was not until the $20^{\text {th }}$ century that Slovakia gained its independence in three forms of state-law organization. In the interwar period Slovakia together with the Czechs was part of the $1^{\text {st }}$ Czechoslovak Republic. During the World War II the independent Slovak state was established. The modern post-war state organization has stabilized in the direction of building the Czechoslovak Socialist Republic. It was the official name of the socialist state formation in the territory of today's Czech Republic and Slovakia from July 11, 1960 to March 29, 1990. Even from the point of view of this short summary, it is easy to justify the great efforts of the Slovaks to support national identity, independence and seek space not only for the economic development, but also for the growth of culture and education of the nation.

\section{Evaluation of bilateral status and situation of national minorities - Polish in Slovakia and Slovak in Poland}

The current Polish national minority in Slovakia consists of those who came to work or study at different times, set up families and stayed here. The Polish minority is also represented by descendants of persons who came to Slovakia during or immediately after World War II. Last but not least, Polish gorals from the SlovakPolish border area are considered to be a large Polish minority in our country.

Until World War I Poles in Slovakia had no cultural-educational organizations or Polish schools. The Polish Reading Room [Polská čitáreň] was the first such 
institution, founded in 1925 by workers of the Polish Consulate in Košice. The reading room served as a library in which Polish books were made available. Apart from the reading room, the Club of Polish Youth and Their Friends [Krúžok polskej mládeže a jej priatelov] were established.

Another organization with a similar purpose was the Polish Club [Polskýkrúžok] in Bratislava operating from 1928 to 1938. Its activities focused on the organization of the cultural life of Poles in western Slovakia and activities aimed at bringing the Polish and Czechoslovak nations closer together. In the interwar period during the 1st Czechoslovak Republic in 1931, 2365 Polish citizens studied at Czechoslovak universities. Polish students in Czechoslovakia set up a student association called Polish Self-Help [Polská svojpomoc]. The branches of this association were established in Prague, Brno and Bratislava. In Bratislava, the association worked at the Faculty of Medicine, Comenius University. Besides that, there were other institutions in Bratislava that arose from the Czechoslovak initiative and in their activities, Poles were actively involved. For example, in 1933 the Polish-Czechoslovak Society in Bratislava [Polsko-československá spoločnost’ v Bratislave] was founded and in 1936 a smaller group of the so-called Slovak-Polish Economic Association in Bratislava [Slovensko-polské hospodárske združenie v Bratislave] was created to be dissolved only a year later. The well-known Polish Institute [Polský inštitút], which operated over the years in the era of socialism, was opened in September 1950 and was first named New Poland [Nové Polsko]. Since 1982 it has been given a new name and has acted as the Polish Information and Cultural Center [Polské informačné a kultúrne stredisko]. Following the changes of the 1989 Velvet Revolution, the Polish Information and Cultural Center has been operating exactly since February 9, 1994, under the name of the Polish Institute [Polský inštitút] and is under the administration of the Polish Ministry of Foreign Affairs. It should be noted that it has been located at the same address at Námestie SNP 27 in Bratislava since 1953.

The role of the Polish Institute is to disseminate information about Poland, popularize Polish culture and deepen Polish-Slovak relationship. The main form of operations are exhibitions in the gallery - about 12 per year. Other events include concerts, lectures, film screenings, authorial meetings, poetic evenings, book presentations, scientific seminars, meetings of writers, linguists and translators of Polish prose and poetry - more than 180 events take place every year. The Institute organizes Polish language courses. The Institute's library contains 10,000 books and 60 magazine titles. The Institute events take place not only in Bratislava, but also in Košice, Žilina, Banská Bystrica, Prešov, Nitra, Levice.

After 1989, the preservation and presentation of the culture of the Polish national minority in Slovakia was extended to other forms and activities proposed by Polish cultural institutions. For example, in February 1991, Adam Mickiewicz's Polish Club [Polský klub Adama Mickiewicza] was founded in Martin. In 1994, its members joined with Poles from Bratislava and Košice in a new association with nationwide scope and established an association called Polish Club - Association 
of Poles and their friends in Slovakia [Polský klub - spolok Poliakov a ich priatelov na Slovensku], which operates also today and has its chapters in Bratislava, Nitra, Trenčín, Dubnica nad Váhom, in Košice. The Polonus [Polonus] civic association can be considered a newer one. It was established in 2007 and has its headquarters in Žilina and a branch office in Martin. It focuses on the development of cultural and educational activities of the Polish national minority living in Slovakia.

Traditional activities and events organized annually by these two very wellcooperating organizations include the Dubnica Days of Friendship, Cooperation and Folklore [Dubnické dni priatelstva, spolupráce a folklóru], Polish Culture Days in Košice [Dni pol'skej kultúryv Košiciach], Let's meet Poland [Potykajme si s Polskom], Friendship Without Borders in Trenčín [Priatelstvo bez hraníc v Trenčíne], Polish Youth Meeting [Stretnutie polskej mládeže] and many others.

The education of children and youth, members of the Polish national minority in Slovakia, is provided exclusively by non-profit organizations. Only the Polish Saturday-Sunday school in Žilina based in Romuald Zaymus Church Primary School in Žilina is registered in the Polish school education system. The Polish Language Club at the Church Leisure Center in Nitra also offers Polish language lessons for preschool children and pupils of first grade of primary school. The School Consulting Center of the Embassy of the Republic of Poland [Školské konzultačné stredisko pri Velvyslanectve Polskej republiky] in Bratislava works on the basis of education for members of the Polish national minority in Slovakia. It was established in 2003 for children of the embassy employees and Polish companies delegated to Slovakia, also for the Polish minority children in Slovakia.

The situation and position of the Slovak national minority living in Poland is very different when we compare it to the Polish minority living in Slovakia. According to the last census in 2011 (as stated in the dissertation of M. Smondek, 2014, p. 58), there are 3000 people living in Poland who belong to the Slovak national minority (Mniejszości narodowe..., 2013, p 17). Based on the census in 2002, Slovak nationality was reported by 208 persons within the Jablonka municipality, 29 persons within the Nižná Lipnica municipality and 15 persons within the Raba Wyżna municipality. According to this census, the Slovak minority does not live in the Czarny Dunajec municipality, which includes Pekelník a Podsklie (Deklaracje narodowościowe...). However, this census indicates there were probably more Slovaks (whether with Polish or other citizenship). At the same time, these estimates, according to other information sources, captured data that out of the number of registered Slovak minorities, only a third of the members mentioned Slovak as their so-called municipality speech. If the level of assimilation of Slovaks should be assessed, for example on the basis of the number of children enrolled in the first year of elementary school, it must be stated that it is quite extensive.

The vast majority of Polish Slovaks live in the Polish part of Orava and Spiš, in the districts of Tatry and Nowy Targ of Lesser Poland Voivodeship. It is a territory belonging to Hungary before 1918, whose population speaks transitional 
Polish-Slovak Goral dialects and which was nationally less aware until the 19th century. It was in the 19th century that both Polish and Slovak revivalists began to operate here, and the result of their activities is that a part of the members of the autochthonous ${ }^{1}$ minority accepted the Polish identity and a part retained the Slovak identity.

The biggest conflict that probably most influenced the relations between Slovakia and Poland was the dispute over the northern part of Slovakia - Spiš and Orava. It happened after the World War I, when new states appeared on the map of Central Europe and with them also the problem of demarcation of new borders. As Milica Majerikova-Molitoris (2013, p. 6) writes: "the former Hungarian-Galician border line was considered one of the most stable in Europe, but already at the end of the 19th century arose in the circle of Polish intellectuals from Galicia so called 'ethnographic theory', which sought to prove the Polish ethnicity of the inhabitants of the northern Spiš, Orava and Kysuce. They proceeded on the assumption that the Goral dialect spoken by that inhabitants is a Polish dialect and, as such, is part of the Polish language. Since language is an essential feature of a nation, its speakers are Poles."

Slovaks inhabit the region of northern Spiš (14 municipalities with a Slovak inhabitants) and upper Orava (12 municipalities with a Slovak inhabitants). These originally purely Slovak municipalities were attached to Poland as a result of the state border adjustment agreement in 1920 between the then Czechoslovakia and Poland, based on a decision of the Council of Ambassadors. According to Jelinek (2009, p 45) finally, the northern borders of Slovakia were determined only in 1924, when the Delimitation Commission (representatives of France, Great Britain, Italy and Japan) annexed the municipalities of Suchá Hora and Hladovka back to Czechoslovakia; parts of the Orava municipality of Nižná Lipnica and parts of the territory near the Spiš municipality of Jurgov, belonged to Poland. Neither side was satisfied with the resolution of the border dispute. The achieved compromise was considered by many Polish and Czechoslovak politicians as an unacceptable loss.

During World War II, in the period of the First Slovak Republic, these territories belonged to Slovakia for six years, also as a product of historical development regions of Upper and Lower Orava, as well as Upper and Lower Spiš were created. They were united ethnically and territorially during this period. Despite strong assimilation pressures since the end of World War II and the repeated detachment of Slovak ethnic territories, the Slovaks in Poland have maintained their national awareness and are trying to preserve their national and linguistic identity through

1 Autochthonous/indigenous (op. immigrated) - domestic, locals, native, autochthonous inhabitants, p. also original, which is from the beginning, which has kept everything as it had at its origin (op. non-original). According to the dictionary of foreign words: https://slovnik.aktuality. sk/synonyma/?q=autocht $\% \mathrm{C}_{3} \% \mathrm{~B} 3 n n y$ 
federal activities. They claim to be Slovaks speaking Goral dialects (Smolińska, 2008, p. 37).

Robert Ištok (2011, pp. 49-50) writes about it: "Requirements of Poland were successfully implemented on part of Slovak territory during the period of weakening of Czechoslovakia. At the end of 1938, 4 municipalities in northern Orava and Spiš, as well as parts of three municipalities in Kysuce (total $226 \mathrm{~km}^{2}$ ) were attached to Poland. These relatively moderate demands resulted from efforts to keep some Slovak circles satisfied. However, this development, together with the previous tearoff of the territories in the north of Orava and Spišs, led to the Slovak revenge policy, which resulted in the participation of the Slovak army in the campaign against Poland in September 1939 and the temporary attachment of these territories to the Slovak State. By contract with Germany dated on November 21, 1939, Slovakia acquired $720 \mathrm{~km}^{2}$ of the disputed territory. After the liberation, northern Orava and northern Spiš, despite the efforts of the Czechoslovak government, by the intervention of the Soviet Union returned to Poland on the basis of the so-called Prague protocols of May 20, 1945. Thus, the Polish-Czechoslovak border from 1921 was restored."

Robert Ištok further describes the period after World War II: "During the post-war period there was a relative improvement in Polish-Czechoslovak relations. Mutual animosities were eliminated by the need for cooperation within the Communist bloc and by the promotion of the concept of proletarian internationalism. The historical burden, arising from border disputes, as well as the events of 1938 and 1945, were gradually overcome. Paradoxically, cross-border contacts have been limited by reducing the number of rail and road crossings. Mutual contacts were also diminished by tightening the regime at the borders after the events in Poland in the early $198 \mathrm{os}$. After complicated peripeteia of Polish-Slovak relations, mutual contacts increased after 1989, and also after the establishment of the independent Slovak Republic.

Poland is one of the few states where Slovaks are recognized as indigenous national minority, which means that the protection of their national, linguistic and cultural identity is ensured by the highest mechanisms binding in the European Union. The regional cross-border neighborhood of 26 Slovak municipalities of upper Orava and northern Spiš with Slovakia and the organic interconnection with lower Spiš and lower Orava should also have a positive effect in this respect. Despite these favorable factors, however, a relatively intense assimilation must be noted, supported most by linguistic, cultural, value and religious compatibility, and thus a lower degree of „vigilance and immunity” to natural as well as intentional assimilation pressure. They are trying to adapt this knowledge in the future to the goals and intentions of the currently representative Association of Slovaks in Poland [Spolok Slovákov v Polsku]. Slovaks are a state-recognized national minority in the Republic of Poland. According to the law, they are Polish citizens with Slovak nationality. 
Since 1957 the official representative of the Slovaks in Poland after World War II was the common Cultural Society of Czechs and Slovaks in Poland [Kultúrna spoločnost Čechov a Slovákov v Polsku], including the Czech minority living in the Polish part of Silesia. It was not until 1995 that the Slovaks (in the new legal state conditions and after the establishment of the independent Slovak Republic in 1993) created their own representative organization called the Slovak Association in Poland [Spolok Slovákov v Polsku]. It is headquartered in Krakow, in one building with the publishing house and editorial office of Life [Život] magazine. It brings together about 3,000 members who are registered in 28 local groups in both parts of the regions, in Krakow, Warsaw and Tychy. Regionally it is divided into a regional committee for Orava and Spiš.

The Slovak Association in Poland is the umbrella organization of the Slovak minority living in Poland. In particular, it considers its mission to preserve the national awareness of the Slovaks, cultural traditions and language identity. Its role is to represent compatriots in matters related to their country of origin in the cultural and educational fields, in state regional and self-governing institutions, in the organization of cultural and educational events - e.g. language camps, sightseeing tours, knowledge and poetry competitions, intermediation of educational and study activities in Slovakia.

After 1990, a branch St. Vojtech Association [Spolok sv. Vojtecha] intended for the Slovak minority in Poland was established. It has about 500 members. In addition, the local departments of Slovak Foundation [miestne odbory Matice slovenskej] in Orava and Spiš were gradually established, with the support of the local departments of Slovak Foundation in Slovakia from neighboring regions and its headquarters in Martin. In many villages, local clubrooms of the Slovak Foundation are founded.

The life of the Slovaks in Poland is closely related to the church life. After the World War II, and especially in the 196os, the Polish Church was partly involved in the violent assimilation - the polonization of the original Slovak population. In 1991, the Central Committee of the SAP [Ústredný výbor SSP] drafted the Memorandum of the Slovak Minority, in which it asked to respect the national rights of Slovaks in Poland, also to introduce the Slovak Catholic worship, to stop anti-Slovak attacks in the press and solve the problems of Slovak education. In December 1991, Slovak worship services were introduced in Jablonka (Orava) and Kacvin (Spiš), one year later also in Jurgov. Worship is currently in six parishes in Spiš and one in Orava. Gradually these included the village of Nedeca.

On various occasions, compatriots not only verbally point out the need to expand and renew Slovak parishes in other villages where Slovaks live. In the past, they have officially turned to the Kraków Metropolitan Union with such a request. These include Slovaks in Podwilk (St. Martin's Church) and Chyžné (St. Anne's Church), where services is only in Polish language. The activities of the Association of St. Vojtech greatly contributed to a noticeable upheaval of the spiritual life. 
A special chapter in Polish - Slovak relationships is the area of minority national education. Historical archives say that the teaching of Slovak language on Polish territory began in the school year 1951/1952 when the Slovak high school (liceum) with the general education curriculum where Polish and Slovak were languages of instruction opened in Jablonka (Orava). Ten years later - in the school year 1961/1962 - there were the last graduates who graduated from all academic subjects in Slovak language. Regarding the evaluation of the participation of Slovaks in the field of science and research in Poland, it should be noted that this area is not subject of systematic activity of any organization of Slovaks in Poland. However, many of my compatriots work as science researchers at Polish institutions, corporations and universities.

The most important journalof Slovaks living in Poland is currently their sociocultural monthly Life [Život] (as mentioned above). It is regularly published on 36 pages in 2300 printed copies. Life magazine is sent to several European countries, USA, Canada. Nowadays, it is one of the richest magazines in content and illustration, which is regularly published outside of Slovakia. It is the result of several years of work of changing editorial teams, the work of innumerable groups of correspondents and persistent interest in the environment of the Slovak national minority. The association prints the magazine in its own printing house, built mostly with the help of the Slovak government. The printing house has modern technology, so besides the magazine and publications for Slovaks, it also provides services to other customers.

So far, no radio station has offered regular broadcasting to Slovak compatriots. Polish broadcasts only sporadically present reports of more remarkable SAP events. Since 1994, Krakow Television has had a weekly documentary series called In our place [U siebie], which is devoted to national minorities in southern Poland. However, the reports are not in Slovak language, Slovak can be heard only in songs, artistic broadcasting and occasional interviews with Polish Slovaks.

\section{Overview of the history of education in Upper Orava2 from the period of Austro-Hungarian Monarchy until now}

The effort to establish the first school in Upper Orava, specifically in Oravka, can be found in the middle of the 17 th century. In the chapter of the Catholic Mission in

2 We issue from the presentation of the results of historical analysis in the dissertation thesis of Mgr. Marián Smondek, PhD., which dealt with the issue of the relationship of family and school in the context of the impact of the school environment on maintaining the national identity of Slovak minority residents living in Upper Orava, Poland. The author focuses on the historical context, which was ultimately reflected in the state educational policy towards minorities in Poland, not only in the past, but they are part of the school policy and ratios of the school system in Poland even nowadays. The dissertation thesis clarifies the history of the Slovak national minority, the conditions for the establishment and gradual dissolution of the Slovak minority 
Orava, Jozef Gebura states that in 1651 the place for the church and the school was remitted at the behest of the king (Štepitová, 2006, p. 233). However, more reliable data is provided by canonical visitations from the first half of the $19^{\text {th }}$ century. Thanks to them we learn that schools in this area were founded in the second half of the 18th century, such as in Nižná Lipnica in 1758, or in Horní Pekelník. Most of the schools were church schools, in some municipalities there were also olk public schools, in Chyžné even two. However, there were only two municipalities with folk common schools in the whole Orava region, besides Chyžný also Kňažia.

It was not until the turn of the 19 th and $20^{\text {th }}$ centuries that some schools were nationalized under the influence of Hungarianization (Michalicka, 2001, pp. 81-83), in the period before the annexation of Upper Orava (also together with Suchá Hora and Hladovka) to Poland. There were a total of 30 schools in this area, of which five were state schools (three in Horná Zubrica and two in Chyžné), eight public schools (four in Jablonka, three in Horná Lipnica and one in Dolná Zubrica) and seventeen Roman Catholic schools (five in Dolná Lipnica, two in Pekelník, two in Podwilk and one in Bukovina-Podsklie, Harkabuz, Hladovka, Horná Zubrica, Jablonka, Oravka, Sŕnie and Suchá Hora). By the end of World War I, in 1918 all of them were taught in Slovak language and after increasing Hungarianization pressure, more and more subjects were taught in Hungarian language (MajerikováMolitoris, 2012, p. 12).

In the interwar period in Orava, but also in Spiš, most schools in selected villages were in 1920 under the church administration and these territories until 1925 were under the jurisdiction of the Spiš Chapter, thus under the administration of the Slovak bishop. However, the Polish school system did not recognize church schools because in Poland all schools were state-owned. Thus, on 2 September 1920, the Polish administration took over the existing education under its leadership (Roszkowski, 2003, pp. 839-841). This caused considerable tensions in Polish Slovak relations. Poland expelled Slovak teachers, abolished all Slovak schools and began to assert a harsh Polonization policy by banning the use of the Slovak language at home as well as in official and public relations (Garek, 2007, p. 177). By doing so, the Republic of Poland ignored the Little Versailles Agreement of 28 June 1919, which obliged Poland to protect national and other minorities (Ciągwa, 1993, p. 7). However, this met with resistance from the Slovak inhabitants. Parents refused to send children to Polish schools. The authorities gradually eliminated this negative attitude by various reprisals and financial penalties (Bielovodský, 1946, p. 135). Finally, in 1920 it managed to open 25 schools in the Upper Orava, but there were also municipalities where it was not taught at all. Teaching began in Podsklie in March 1922, followed by Podsŕnie (Majeriková-Molitoris, 2012, p. 14). Although access to Slovak literature in schools was completely barred, Slovaks found a way

education. It reflects on importance and role of the minority school in a nationally mixed border environment. 
to teach and have access to the Slovak language in their homes by reading Slovak literature, which was supplied by the Association of St. Vojtech in Trnava. A certain change in the approach to the Slovaks was suggested by the reform of 1933, which recommended the introduction of an optional subject: the language of the nearest neighboring nation in middle and high schools. As a result of the introduction of the reform, Slovak and Czech languages were taught at the Nowy Targ Gimnasium and Liceum from 1933 to 1939.

The situation in Orava changed significantly after the outbreak of World War II. Slovak armies occupied the Upper Orava and the territory was incorporated into the Slovak Republic. Since September 1939, particular schools have been taken over by Slovak teachers who, on the basis of decrees issued by the School Inspectorate in Dolný Kubín, have been appointed as their administrators. However, during the Slovak State, the organization of school teaching in these border schools was not without problems. The biggest problem was the shortage of teaching staff, because a large number of children in each municipality was taught by only few teachers. There was not a single school in Orava that had enough teachers. We can mention examples in the following municipalities: Pekelník - 265 pupils taught by two teachers, Bukovina - Podsklie 170 pupils taught by four teachers (Garek, 2010, p. 224), Sŕnie - 104 pupils taught by two teachers, Nižná Zubrica - 153 pupils taught by three teachers, Nižná Lipnica - 173 pupils taught by three teachers, Oravka - 145 pupils taught by three teachers (Hojová, 2013, p. 141). Nevertheless, the difficulty of finding accommodation for teachers has been added to these problems. It was necessary to invest in the repair of school buildings because they were in poor condition. The number of classes was insufficient for the number of school age children. The lack of teachers was eventually handled by alternate teaching at several schools. The problem also occurred with current schoolbooks, Slovak school aids and Slovak books at all.

Another problem was the school management system. In 1940, the Slovak administration was inclined to reinstate schools that until 1920 belonged to the Church. Some residents disagreed with this arrangement because of the state funding of schools. Even some of the Church administrators were not interested in such an arrangement. Altogether there were 25 schools in Orava. Based on archival findings, we know that only those schools that had been run by the church before 1920 within the church administration. During the war, in 1940 the Folk School of Economics in Dolná Zubrica was established. Also, in the same year in Jablonka was established the New Town School for Upper Orava. In the first school year, 99 pupils attended this school. They were taught by three teachers. In the school year 1944/1945, a temporary one-year training course for teachers was also set up at the town school in Jablonka (Garek, 2010, p. 225). In 1944, 3639 pupils in 80 classes studied at Orava. Following the order of the Slovak National Council of 6 September 1944, all schools were re-nationalized. The Slovak education was functioning in Upper Orava until the end of the school year 1944/1945 (Garek, 2007, pp. 178-179). 
The development of education and school policy in the post-war period again noted major changes and a new arrangement of conditions. One of the first measures was that the municipalities in Upper Orava and northern Spiš were re-annexed to Poland. The establishment of new rules and order was not accompanied by small problems. Funding required for further development of the Slovak minority education was withdrawn. In September 1945, the Polish side proceeded to open only Polish schools with the order to displace all Slovak teachers. Except that only 18 out of 27 elementary schools were opened in Orava, these Polish schools also had a lack of qualified teachers. The issue of minority education was not a priority, and Slovak parents often resisted assimilative Polonization. Several students from Upper Orava therefore continued to attend schools in Slovakia after the municipalities were annexed to Poland. They attended a middle school in Trstená, Trnava, Rožňava, Bratislava, Banská Bystrica, Kláštor pod Znievom, also town school in Tvrdošín, Levoča and state folk schools in the near borderland. Several students attended Czechoslovak universities.

A new chapter of the Slovak education in Orava was opened after the signing of the Treaty of Friendship and Mutual Assistance between the Czechoslovak Republic and the Republic of Poland dated March 10, 1947, along with which an additional protocol was adopted, which, on the basis of the principle of reciprocity, also included the issue of minority education.

So much from the perspective of the history of minority (Slovak) regional education in Upper Orava.

\section{Conclusion}

In conclusion, it is necessary to summarize the knowledge that the Polish and Slovak Republics are autonomous and sovereign states integrated into unified European organizations and structures of the European Union. The accession of Poland and Slovakia to the European Union brought new impulses for the development of cross-border cooperation and at the same time opened up new possibilities for financing common projects, including within the framework of the European Union programs intended generally for culture and especially for education. The need to develop minority education for the enhancement of national identity and national awareness is not so important now as it was in the past. This is also reflected in the current trends in access to minority schools in Upper Orava. At present, there are only two elementary schools with the Slovak language of instruction in Poland - in Nová Bela and Jablonka, while Slovak is taught only at the first stage (grades 1-4). In higher grades, only some subjects are taught in the Slovak language. In another 25 elementary schools, Slovak language is taught as a compulsory language only by the parents' decision. In total, about 650 pupils are currently learning Slovak language in these minority schools in Upper Orava. There are problems with the provision of teaching mainly because there are few 
Slovak teachers in schools. Conversely, where teachers are, there are often not enough enrolled children. Recently due to lack of interest of parents the Slovak language was terminated at the schools in Podwilk and Chyžné. In secondary education, the only option for children from Slovak familiesis the mentioned high school in Jablonka, where 48 students are now learning Slovak. In I. C there are 14, in II. B 16, in III. C 12 and IV. C class are 6 students who will graduate in Slovak language. Slovak is taught here as an optional class for 3 hours a week. However, none of these graduates plans to study in Slovakia.

At the university level, the Slovak language is taught at the Jagiellonian University in Krakow. Children have the opportunity to study at schools in Slovakia after finishing elementary school, while scholarships are provided by the Ministry of Education of the Slovak Republic. Approximately 50 students have been attending Slovak secondary schools and universities since the mid-1970s. Most graduates continued their university studies in Slovakia. Several graduates of universities graduated with a doctorate and after returning back improved the quality of the Slovak intelligence community in Poland.

\section{References}

Bielovodský, A. (1946). Severné hranice Slovenska [Northern borders of Slovakia]. Bratislava: Ústredná správa Slovenskej ligy.

Ciągwa, J. (1993). K dejinám Slovákov v Polsku a k ich kultúrnemu vývinu [The history of Slovaks in Poland and their cultural development]. In L. Molitoris (Ed.), Almanach Stowacy w Polsce I. Kraków: Towarzystwo Społeczno-Kulturalne Czechów i Słowaków w Polsce.

Deklaracje narodowościowe w gminach w 2002 roku. Dostępny w Internecie: http:// www.stat.gov.pl/cps/rde/xbcr/gus/PUBL_nsp2002_tabl4.xls (15.1.2014).

Garek, M. (2010). Školstvo na území hornej Oravy v rokoch 1939-1945 [Education in the Upper Orava region in the years 1939-1945]. In P. Sokolovic (Ed.), Život v Slovenskej republike. Slovenská republika 1939-1945 očami mladých historikov IX [Life in the Slovak Republic. The Slovak Republic 1939-1945 through the eyes of young historians IX]. Bratislava: Ústav pamäti národa.

Hojová, M. (2013). K problematike školstva na hornej Orave v rokoch 1939 - 1945 [The issue of education in Upper Orava region in the years 1939 - 1945]. In L. Molitoris (Ed.), Almanach Slováci v Polsku XIV [Almanac Slovaks in Poland XIV]. Kraków: Towarzystwo Słowaków w Polsce - Zarząd Główny.

Huba, P. (2010). Historia a sucasnost: Medzinárodná spolupráca [History and present: International cooperation]. Oravská knižnica Antona Habovštiaka v Dolnom Kubíne.

Hvišc, J. (2008). Slovensko-Polsko: Bilaterálne vztahy v procese transformácie [Slovakia-Poland: Bilateral relations in the process of transformation]. Bratislava: Lufema. 
Ištok, R. (2011). Slovensko a Pol’sko: geopolitické, politologické, historické a humánnogeografické súvislosti [Slovakia and Poland: geopolitical, politological, historical and human-geographical context]. Prešov: Vydavatel'stvo Prešovskej Univerzity. Jelínek, P. (2009). Zahraničně-politické vztahy Československa a Polska 1918-1924 [Foreign-political relations of Czechoslovakia and Poland 1918-1924]. Opava: Matice Slezská.

Kamiński, M.K. (1990). Polsko - czechoslowackie stosunki polityczne 1945-1948. Warszawa: Państwowe Wydawnictwo Naukowe.

Kamiński, M.K. (2001). Konflikt polsko-czeski 1918-1921. Warszawa: Instytut Historii Polskiej Akademii Nauk: Neriton.

Kamiński, M.K. (2005). W obliczu sowieckiego ekspansjonizmu: Polska i Czechosłowacja w polityce Stanów Zjednoczonych i Wielkiej Brytanii: 1945-1948. Warszawa: Instytut Historii PAN: Neriton.

Kamiński, M.K., \& Zacharias, M.J. (1998). Polityka zagraniczna Rzeczypospolitej Polskiej 1918-1939. Warszawa: LTW.

Majeriková-Molitoris, M. (2012). Z dejín hornej Oravy XII [From the History of Upper Orava XII]. Život. roč., 8(650).

Majeriková-Molitoris, M. (2013). Česko-slovensko-pol’ský spor o Spiš a Oravu [CzechSlovak-Polish dispute over Spiš and Orava]. Historická revue, 3, 6-10.

Matras, H. (2011). Desatročie 2001-2010 vstup do nového milénia: Čo je to cezhraničné priatel'stvo nič iné ako... [Decade 2001-2010 entering the new millennium: What is cross-border friendship nothing but...]. Oravská knižnica Antona Habovštiaka v Dolnom Kubíne.

Michalicka, V. (2001). Dejiny oravského školstva do roku 1918 [History of education in Orava until 1918]. Bratislava: Ústav informácií a prognóz školstva.

Mniejszości narodowe i wyznaniowe, kolekcja nasza Polska 81. (2013). Warszawa : De Agnostini

Molitoris, L. (Ed.) (2007). Almanach Słowacy w Polsce XI. Kraków: Towarzystwo Społeczno-Kulturalne Czechów i Słowaków w Polsce.

Purchla, J., \& Vášaryová, M. (2006). Kto sú Slováci?: História Kultúra Identita [Who are the Slovaks?: History Culture Identity]. Krakov: Medzinárodné centrum kultúry v Krakove.

Purchla, J., \& Vášaryová, M. (2008). Modele mecenatu państwa wobec integracji europejskiej: Doświadczenie Polski i Słowacji. Kraków: Międzynarodowe Centrum Kultury.

Smodek, M. (2014). Slovenské menšinové školstvo na hornej Orave [Slovak minority education in Upper Orava]. Dissertation thesis. Bratislava: Comenius University, Faculty of Arts.

Smolińska, T. (2008). Tradičný obraz Slovenska a Slováka v Pol’sku: V kruhu tradičných pol'ských stereotypov [Traditional picture of Slovakia and Slovak in Poland: In the circle of traditional Polish stereotypes]. In J. Hvišč (Ed.), 
Slovensko-Polsko: Bilaterálne vztahy v procese transformácie [Slovakia-Poland: Bilateral relations in the process of transformation]. Bratislava: Lufema.

Sokolovic, P. (Ed.) (2010). Život v Slovenskej republike. Slovenská republika 1939-1945 očami mladých historikov IX [Life in the Slovak Republic. The Slovak Republic 1939-1945 through the eyes of young historians IX]. Bratislava: Ústav pamäti národa.

Štepitová, O. (2006). Príspevok k dejinám oravského školstva [Contribution to the History of Education in Orava]. Dolný Kubín: Oravská knižnica Antona Habovštiaka.

\title{
REGIONALNE STOSUNKI POLSKO-SŁOWACKIE A ROZWÓJ MNIEJSZOŚCI SŁOWACKICH SZKÓŁ W POLSCE W REGIONIE GÓRNEJ ORAWY
}

\begin{abstract}
Streszczenie: Artykuł dotyczy sytuacji edukacji mniejszości słowackiej w regionie Górnej Orawy w Polsce. Sytuację i ogólny stan rozwoju edukacji mniejszościowej ocenia się głównie z perspektywy historycznego rozwoju warunków społecznych, co wpłynęło nie tylko na politykę szkolną, ale również szeroko rozumiany rozwój myślenia pedagogicznego w Polsce. W ciągu ponad dwóch stuleci (od XVIII wieku do chwili obecnej) ułożono wiele historycznych kamieni milowych w przygranicznych stosunkach polsko-słowackich, które również wpłynęły na funkcjonowanie słowackich szkół w Polsce. Znajduje to odzwierciedlenie w sporach terytorialnych i językowych, które wpływają głównie na tożsamość narodową Słowaków. Autorka zastanawia się nad znaczeniem i misją regionalnych szkół mniejszościowych w obszarze przygranicznym Polski i Słowacji, jakim jest Górna Orawa. Podkreśla jednoczącą rolę i promowanie dobrego współistnienia i kształtowania otwartej i obywatelskiej tożsamości narodowej (etnicznej) Słowaków mieszkających w Polsce w regionie Górnej Orawy.
\end{abstract}

Słowa kluczowe: mniejszość; edukacja; związki; region. 